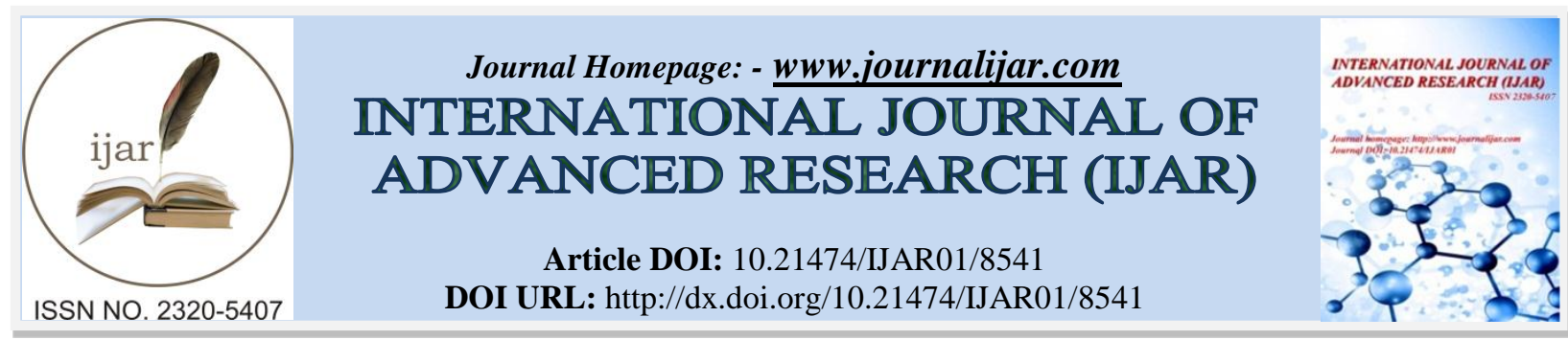

RESEARCH ARTICLE

\title{
A CLOSE LOOK AT THE NEEDS AND CHALLENGES FACED BY SENIOR HIGH SCHOOL STUDENTS OF THE ACCOUNTANCY, BUSINESS, AND MANAGEMENT STRAND.
}

\author{
Rongie C. Abella. \\ College Instructor, College of Teacher Education, University of Cebu - Main Campus, Cebu City, Philippines.
}

\section{Manuscript Info}

Manuscript History

Received: 11 December 2018

Final Accepted: 13 January 2019

Published: February 2019

\section{Key words:-}

senior high school, needs and challenges, work immersion, qualitative, case study, Asia.

\section{Abstract}

This qualitative study aimed to better understand the needs and challenges faced by Senior High School (SHS) Accountancy, Business, and Management (ABM) students in their journey of learning real life business problems. It utilized a case study method in which the unit of analysis is the SHS Grade 11 and 12 ABM students of Simala National High School, a secondary public school in Cebu, Philippines. Analysis of transcribed interviews and observations from 20 key informants revealed the findings encapsulated in the following themes: a) 'Clamor for Work Immersion' which explains the need to expose the learners to hands on real world business activities; b) 'Demand for Learning Resources and Facilities' which entails the need for adequate print and non-print learner's material, computers, and unlimited internet access; c) 'Request for Skilled and Experienced Teachers' which relates the need to hire teachers who are business graduates or have firsthand business experience; d) 'Time runs fast' which reveals the challenge of allocating enough time in all their projects particularly those involving data gathering outside school; and e) 'Funds empty fast' which shows the challenge of budgeting their allowances to be sufficient for their school requirement expenses. The school administration and teachers shall then address the needs through enhancing the work immersion plan, intensifying the school improvement plan, and hiring of qualified teachers. To cope with the challenges, the students need to develop time management skills and properly set priorities on where to allocate their available finances.

Copy Right, IJAR, 2019,. All rights reserved.

\section{Introduction:-}

The $\mathrm{K}$ to 12 Basic Education Curriculum has been the biggest change in the Philippine education system in these modern times. With the addition of two years that constitute the senior high school, it has extended the basic education from 10 years to 12 years which is at par with international standards. The main goal of this curriculum is to holistically develop Filipinos with the $21^{\text {st }}$ century skills and uplift their standard of living (Okabe, 2013). Its full implementation has now been in placed through the advent of Senior High School (SHS) program. Junior High School completers are to choose the track to be pursued in SHS that they believe will equip them with skills for the degree they wish to achieve in higher education or the vocational job they want to engage once they graduate. The Academic track has been observed to have huge number of enrollees because of its promising feature of preparing

Corresponding Author:-Rongie C. Abella.

Address:-College of Teacher Education, University of Cebu - Main Campus, Cebu City, Philippines. 
the students to the college courses of their choice and eventually get a high paying white collar jobs. Specifically, Accountancy, Business, and Management (ABM) as one of the strands under the Academic track assures the students to prepare them to any business related courses as reflected on its subject offerings and curriculum guides. It is believed that business education is an integral part in coping with the necessary requirements and demands of a $21^{\text {st }}$ century world (Berry, 2013).

However, it has been observed that education in most schools these days is very theoretical rather than experiential where students are not personally involved in business experiences (McHann \& Frost, 2010). Chia and Holt (2008) stressed that most students do not have opportunities such as trainings or skills development in which they can apply their knowledge into real world practice. Not surprisingly, a serious knowing-doing gap is very evident among business graduates which eventually affects their productivity and competitive success (Pfeffer \& Sutton, 2000). Section 5 of Enhanced Basic Education Act of 2013 specifically states that the Department of Education shall adhere to the following standards and principles in which the curriculum shall use pedagogical approaches that are constructivist, inquiry-based, reflective, collaborative and integrative. With this provision, it is mandated that the teaching and learning approaches employed in the classrooms should uphold the features of a constructivist classroom which are democratic, student-centered and the learning process encourage the students to be independent and responsible. Situated cognition theory emphasizes that people's knowledge is constructed within and linked to the activity, context, and culture in which it was learned (Robbins \& Aydede, 2009). Making connections to everyday contexts guides students to enrich and integrate schooling and life experiences and further develop meaningful, long-lasting interests and understandings (Jonassen \& Land, 2012). Since the senior high school program in the Philippines is still in its infancy stage, the schools offering the ABM strand would face a lot of challenges as they are still inexperienced on how to satisfy and cope with the demands of this program.

There are still less researches about how the ABM specialized and applied subjects will be carried out in order for the students to experience that their classes are relevant and connected to real life applications. Little is known yet about how students feel throughout the academic journey under this strand and what are the challenges that need to be addressed in order to maximize learning. Thus, it is of significance to understand how ABM students make sense of their experiences in the hopes of learning real life business problems while in school. Taking a close look at their needs and challenges would help the different stakeholders in senior high school develop new learning strategies or educational policies that will bridge the gap between the academe and industry.

\section{Objectives Of The Study:-}

The purpose of this qualitative study is to better understand the needs and challenges of Senior High School Accountancy, Business, and Management students in their journey of learning real life business problems.

\section{Research Questions}

1. What are the needs of the students who enrolled in Accountancy, Business, and Management (ABM) strand in learning real life business problems?

2. What are the challenges experienced by ABM students in their specialized and applied subjects as they apply what they have learned in real life business problems?

3. How do ABM students describe these needs and challenges as factors affecting their goal of learning real life business problems?

\section{Methodology:- \\ Design}

This qualitative study utilized a case study method in which the unit of analysis is the SHS Grade 11 and 12 ABM students group of Simala National High School. A case study is an in-depth description and analysis of a bounded system. The single most defining characteristic of a case study research lies in delimiting the object of the study: the case. It is less of a methodological choice but a choice of what is to be studied which is a single unit around which there are boundaries (Creswell, 2016). It shares with other forms of qualitative research the search for meaning and understanding. The researcher is the primary instrument of data collection and analysis of the results and the product is a rich description of the experience under study. Data are collected through interviews, observations, and document analysis. The analysis of the data involves identifying recurring patterns that characterize the data. Findings are these recurring patterns or themes supported by the data from which they were derived. The overall interpretation will be the researcher's thoughts of the participants' understanding of the occurrence of interest (Merriam \& Tisdell, 2015). 


\section{Key Informants and Locale}

This study utilized purposive sampling. The primary sources of data in this study were the 20 out of 36 students of Grade 11 and 12 Accountancy, Business, and Management (ABM) sections of Simala National High School currently enrolled for school year 2017 - 2018. The informants are consisted of ten females and ten males with ages ranging from 15 to 18 . They were all regular students with good grades and have never been failed in any of the subjects in SHS. They have good attendance record with no more than five absences for the last school year. They have already undergone applied and specialized subjects under the ABM strand.

The site of interest for this study is Simala National High School, a secondary public school in Cebu, Philippines. It has approximately 1, 200 students distributed into 23 class sections. The school is offering senior high school with four specialized programs which are the General Academic Strand (GAS) and Accountancy, Business and Management (ABM) for the Academic Track and Carpentry NC II and Cookery NC II for Technical-VocationalLivelihood (TVL) Track.

\section{Instrument}

The research tools utilized to gather necessary data are semi-structured interviews, observations, and analysis of documents such as the report cards and attendance records of the key informants. The 10-item semi-structured interview questionnaire was checked and validated by three experts if it was in consonance with the research questions. It was also pilot tested to five ABM students to check if there were words and phrases which were not clear or can cause misconception.

The interviews were done in a face-to-face manner during the free period of the informants. Permission was asked to the informants to record the interview so that transcripts can be made. Each interview lasted for $15-20$ minutes. Furthermore, the researcher noted down and richly described the observations of the behaviors and attitudes of the respondents during classes and vacant periods. Since the researcher is the class adviser and one of the specialized subject teachers of the informants, observations were done anytime of the day. Documents such as report cards, anecdotal record, and daily attendance report were analyzed to supplement and validate the interviews and observations.

\section{Data Analysis}

In determining the number of key informants needed in the study, data saturation was primarily considered. Merriam and Tisdell (2015) pointed out that saturation occurs when continued data collection produces no new information or insights into the phenomenon being studied. Secondary sources of data were the teachers of their specialized and applied subjects and school documents.

The research study is qualitative design in nature thus it utilized the researcher as the primary research instrument. Developing common themes or patterns that intersect the data was the primary method of data analysis. Hence, the researcher was guided by the inductive and comparative strategy of analyzing the data.

To organize the data, coding was utilized. Coding for the purpose of developing concepts can be done by intensive examination making central classification account for the majority of data (Creswell, 2016). In other words, it is assigning a short designation to different aspects of the data gathered so that specific data can be looked at easily. Most often a code is a word or short phrase that symbolically assigns a summative, salient, essence-capturing, and/or evocative attribute for a portion of language-based or visual data (Merriam \& Tisdell, 2015). Specifically, this study will apply analytical coding which is the kind of coding that comes from interpretation and reflection on meaning.

The identified themes or categories of the data should be the aligned and answered the research questions. Since as a qualitative analyst the researcher do not have a statistical test to help tell when an observation or pattern is significant, the researcher must rely first on his own sense making, understanding, intelligence, experience, and judgment (Creswell, 2016). The themes formed from analytic coding became the findings of the study.

Prior to analysis, a table was drawn containing the real names of the key informants with its corresponding assigned letter. The researcher looked at this table every time he attributed a quote to a particular informant. Informant's answers which were in the vernacular were translated into English. The translation was consulted back to the informant to verify if it entirely captured what he/she was trying to convey. All identifying information in the discussion was removed to maintain the privacy and confidentiality of the key informants. 


\section{Ethical Consideration}

The researcher guarantees that the key informants were not forced or subjected to any threat in providing the necessary data for this study. They did not answer questions that they found offending or uncomfortable that is why no guidelines were imposed on how much they answered. Since all of the respondents are minors as of to this writing, an assent form was given to them and an informed consent was asked from their parents or guardians to be read, understood, and signed.

The gathering of data was done in a suitable time and place and no harm in any form such as physically or emotionally was inflicted to the respondents during interview sessions. They were free to answer or give their opinions without any consequences at their disadvantage. Their answers were treated with confidentiality in the part of the researcher. On top of it all, the outcomes of this study are expected to uplift the standards of educational practices and address implementation problems and issues that will soon be of great benefit to all senior high school students.

Since the researcher is an educator, the results were interpreted in a way that helped uplift the educational standards and provided significant information on how to address realistic and meaningful learning of the students.

\section{Result and Discussion:-}

Table 1 reveals the different codes generated from the transcripts made from the interviews done with the key informants. From the codes produced, five themes were formulated representing the needs and challenges of the SHS ABM students. These themes are the following: Clamor for Work Immersion, Demand for Learning Resources and Facilities, Request for Skilled and Experienced Teachers for the needs while "Time runs fast." and "Funds empty fast ." for the challenges.

Table 1:- Codes and Themes

\begin{tabular}{|l|l|}
\hline \multicolumn{1}{|c|}{ Codes } & \multicolumn{1}{|c|}{ Themes } \\
\hline Needs & Clamor for Work Immersion \\
\hline $\begin{array}{l}\text { real life application/ dealing business/ on the job training/ outside activities/ } \\
\text { interviewing/ more hands on activities/ actual job/ firsthand experience/ field } \\
\text { study }\end{array}$ & $\begin{array}{l}\text { Demand for Learning } \\
\text { Ro books/ no learning resources/ not enough computers/ no printers/ no free } \\
\text { internet access/ no visual materials/ not enough televisions and projectors }\end{array}$ \\
\hline $\begin{array}{l}\text { give paperworks only/ not business inclined/ not a business graduate/ not subject } \\
\text { expert/ do not know business terms/ rely on one source/ cannot relate }\end{array}$ & $\begin{array}{l}\text { Request for Skilled and } \\
\text { Experienced Teachers }\end{array}$ \\
\hline Challenges & Time runs fast. \\
\hline $\begin{array}{l}\text { not enough time for everything / too many projects and assignments/ group } \\
\text { project outside school/ outside people don't cooperate/ a lot of subjects/ internet } \\
\text { research takes time }\end{array}$ & \\
\hline $\begin{array}{l}\text { not enough allowance/ a lot to print and encode/ buy materials for projects/ put up } \\
\text { capital when selling/ group contribution/ hard to budget }\end{array}$ & Funds empty fast. \\
\hline
\end{tabular}

\section{Needs}

Theme No. 1: Clamor for Work Immersion. The primary goal of the Senior High School program is to let the secondary students master the prerequisite skills needed in professional courses and equip them with employment and industrial skills (Estonanto, 2017). Thus, most of the informants expressed their clamor to be immersed in real world practice of their chosen SHS major. These Accountancy, Business, and Management students want to experience the actual job of doing business related activities. Key informat B related: "I really want to try working in a business related job outside school because for me experience is the best teacher." The students are clamoring for first hand experiences and not just listening to theories inside the classroom. They want hands on activities because they believe these can actively engaged them in the lesson. Students who actively engaged in the lesson they are studying tend to have better understanding and retention. They enjoy more and are able to appreciate the relevance of what they have learned (Park, 2003).

Doing field studies and interviews of the practitioners in different business establishments are highly preferred by the informants as they learn what are really practiced in the industry. Key informant $\mathrm{H}$ shared: "It would be better if 
we can do field study in the stores or any other business outside so we can interview the manager of what they are really practicing in real life." Learning business concepts inside the classroom would create doubts among students since they do not witness it yet if they are really applied in real life. Further, the researcher observed that during classes when complicated terms and business jargons were discussed already, most of them could not relate anymore and tend not to care about the lesson. Thus, the trend now is to situate learners at the center of the experience, empowers them to be responsible for their own learning, and encourage them to see themselves as active thinkers and problem solvers (Park, 2003).

During the $2^{\text {nd }}$ semester of every year, all SHS students will have their work immersion as one of their specialized subjects. They are required to render a total of 80 hours of duty to comply with the subject. They have been assigned already to various industry partners with activities related to their specialization and they are required to render 8 hours of duty for ten Fridays. They are hoping that the one who will handle them in their immersion venue would trust them in dealing with business transactions so that they will have more hands on experience related to their major. Key Informant $\mathrm{C}$ said with a doubt: "Hopefully, they will trust us to handle the papers related to their business so that we can be exposed."

Work Immersion is indeed needed by the SHS ABM students so that they can master the skills required in their major in preparation for a job. "We really need to go outside the school because the job we are preparing are in there." These findings agree with the strict implementation of the Department of Education to let the students undergo work immersion as a requirement for their graduation. This further confirms that the curriculum was designed to respond for the standardization of the educational system in the country to meet the global standards (Estonato, 2017). Thus, the school should enhance the work immersion plan by looking for work immersion partners where the students can learn more and will be given opportunities to apply what they have learned in school.

\section{Theme No. 2: Demand for Learning Resources and Facilities.}

One critical variable that has a direct impact in the quality of learning acquisition is the adequacy or lack of school facilities that is necessary in reinforcing the knowledge and skills among learners (Limon, 2016). The lack of materials and facilities for the students in Simala National High School was one of the needs highlighted in the interviews. Key Informant D explained: "There is no proper computer lab for the students to do research which is much needed in our practical research subject." Though the school has one computer laboratory with 40 units of computers, the access to this facility was limited. The school ICT coordinator would not let students to research anytime without the presence of their subject teacher. Most of the time, classes in other grade levels are held in the laboratory which will give no available time-slot for the SHS students to do their research. "We cannot book a schedule in the ICT room because it is fully booked most of the times". This inadequacy of computers available for the SHS ABM learners would somehow affect the performance of the students. As we know, technology can be powerful in improving learning particularly when there is regular and frequent use (Higgins et al., 2012). So for the students to comply with the requirements involving researching in the internet, they usually go to the internet shops where an hour of usage would cost them 15Php plus additional amount for printing their outputs. Since they can only go there after class hours, some would go home already late and thus, facing their angry parents. "Once I arrive home late from internet cafes, my mother would have this angry look that really scares me."

Oftentimes, students are just going to use their smart phones for quick research however they are not able to access the school wifi. The password was not disseminated to the students. "We cannot access the school wifi because we are not given the password. We just use data instead to access internet." According to the school ICT coordinator, the wifi password is intentionally kept secret from the students. He explained that if a lot of students will access the wifi at the same time, it will result to a very slow internet which affects the internet access of the computer units in the ICT room. It would be way better then to upgrade the internet speed of the school wifi in which it can cater to large number of users. This has been raised up already in the administration but to no avail as of to this writing.

Learning resources are also one of the needs emphasized by the informants. Learning resources include print and non-print materials; audio, visual, electronic, and digital hardware/software resources (PEI, 2008). These learning resources were not utilized by most of the teachers in aid of learning. Key Informant I shared: "We are having a hard time if we cannot see any visuals or printed examples during class discussions." To make it worse, no book or learner's material has been provided by the Department of Education for ABM's applied and specialized subjects. "There is no book that we can read if we want to study the lessons especially in accounting. Thus, we got low scores in our exam." 
This impact of the lack of resources and facilities to the learner's performance should be looked into by the school administration and higher offices since internal and external resources interrelate to achieve holistic learning within a learner (Limon, 2016). The school should do its best to provide adequate facilities so that SHS ABM students can maximize learning and connect to real life examples through research. With the advent of computers and internet, the school should invest in these resources and facilities. These resources should then be included and prioritized in the school improvement plan so that enough budget can be allocated for its purchase.

\section{Theme No. 3: Request for Skilled and Experienced Teachers.}

For a teacher to be considered expert, he identifies key ideas, presents them in several ways, and highlights connection among those ideas (Island, 2008). This kind of teacher has been the expectation of ABM students to teach all their subjects in senior high school. Key Informant A shared: "We are hoping that our teachers are experts in our major subjects." However due to lack of available teachers who are skilled and experienced when it comes to business related activities, the school chose to utilize the current pool of teachers in school who were hired for senior high school to teach the specialized and applied subjects of ABM strand. "Our teachers before are also our teachers in senior high and sometimes they cannot relate on some business terms." Thus the interviews from the key informants revealed that there is a great need for skilled and experienced teachers who can help ABM students connect and visualize real life business problems.

Key Informant E explained: "Our teachers are not business inclined and they do not have experiences related to business hence they cannot share any experience to us." ABM students are very much eager to listen to real life business experiences so that they will be able to connect with the practicality of the concept in their major. However, their current teachers of specialized and applied subjects gave little to no stories on how the concepts are applied in real world. "Most of the teachers are just going to give paperworks with no explanation because they too are having difficulty with the terms." In this instance the learning are affected especially that good organization of the subject matter and planning of the course are important for the students to learn best (Henard \& Leprince-Ringuet, 2008).

The school has been sending the senior high school hired teachers in various seminars. However due to the conflict of schedules, teachers handling ABM specialized subjects were not able to attend the seminar intended for those subjects. Further, the teachers were just provided curriculum guides and not a single teacher's guide on how to handle the subject has been provided by the Department of Education as of to this writing. Hence, this need should be addressed because studies show that the teacher's length of related experience and specific teaching qualifications correlated to the achievement of the students (Henard \& Leprince-Ringuet, 2008). The school then should hire teachers who finished business related courses to teach the ABM subjects. "Hopefully, we have a new teacher who is really a business graduate or had worked long in a huge company." The quality of teacher is an important factor in determining gains in student achievement (Guerriero, 2013). Through their skills and experiences, it will be clearer and more meaningful to the ABM students connecting the concepts to real world application

\section{Challenges}

Theme No. 4: Time runs fast.

Time management is a skill that every student should not only know but also apply (Nasrullah \& Khan, 2015). Better time management skills can improve grades, help keep stress in check, and help one to be competitive in their undertakings (Poser, 2003). SHS ABM strand has a total of 31 subjects which include 15 core , 9 specialized, and 7 applied subjects. They need to comply these subjects for 4 semesters or 2 academic years. Due to the demand of each subject, ABM students were really challenged in managing their time. Key Informant C related: "We have a lot of subjects and in every subject there are a lot of projects." Thus, effective time management is vital for students to shine and achieve more (Poser, 2003).

Specifically with their applied and specialized subjects where some projects involve communicating and gathering data outside the school, the students were challenged on when to fit these tasks in their schedule. "Our projects especially in marketing involve gathering data outside the school in which we can only do on weekends so our house chores are left behind." They needed to sacrifice their weekend for their projects since on weekdays they are not allowed to get outside the school campus during class hours. "There is really no time on weekdays if the project already involves outside school activity." So most of the times, the students asked an extension of the deadline for the project in which the teachers were willing to give because they understood the time constraints of gathering outside data. 
For their Practical Research subject in which they need to interview various people outside school, the students expressed exhaustion in gathering the data. Key Informant D shared: "We just have limited time to reach out to our respondents and worse, when we get there they do not cooperate." As a consequence, they will not be able to organize duties according to their priorities and get easily distracted resulting for them to procrastinate (Norvilitis, 2006). Their grades are then affected resulting to a lower academic performance.

Time management among ABM students is also affected when they need to research in the internet cafe. Since most of them do not have laptops and worse have no access to school wifi, they needed to visit the internet cafe to do research. They shared that researching in the internet takes time. So when they do the researching during lunchtime, they often got late in the first subject in the afternoon. If they do it after $5 \mathrm{pm}$, they would go home late and face the never ending nag from their parents. "I am always scolded if I go home late and if I tell them that I went to the internet cafe for a project, they wont believe me."

Each student should have an ability to manage time effectively which includes setting goals and priority, using time management mechanisms, and being organized in using time (Nasrullah \& Khan, 2015). Effective time management would reduce academic stress resulting to a better school performance (Misra \& McKean, 2000). Hence, developing these skills would greatly help them cope with the struggles.

\section{Theme No. 5: Funds empty fast.}

There are several factors in which students manage their money such as their age, personality traits, and knowledge (Norvilitis et al, 2006). Thus, every SHS ABM student differ on how they budget and spend their money. Yet, the interviews revealed that all of the key informants were challenged on the expenditures incurred in their projects and activities. Key Informant G shared: "We spent a lot in our projects which is a struggles because we have meager allowance." They had a hard time budgeting their allowance in order to buy the requirements and other expenses related to their projects. They are in a situation where they have restricted incomes and high expenses (Stollak, 2011). Though expenses are expected of being a student, they were caught off guard on how to manage their expenditures now that they are bombarded with projects and costly performance tasks.

Key Informant J related: "We have subjects that we need to contribute money because we need to sell something as our performance task so I need to ask from my mother." Some parents just give them enough allowance so they do some tight budgeting by not buying snacks and spending just a little for their lunch. "Sometimes, I do not eat snacks and just buy cheap viand so that I can contribute to the group project." They also have activities in which they need to meet outside the school on weekends and it is an additional expense for them especially with the fare and snacks. "We meet with our group on weekends especially in Marketing and Practical Research to gather data for our project which entails another expense." They confessed that their parents complained to them already when they always meet with their classmates even on weekends since it would cost them additional allowance.

Most of their expenses are incurred in internet cafes and printing paper works. Key Informant A claimed: "There are a lot to print and each page is costly that is why it is hard to budget my allowance." They sometimes asked their teacher if some of the outputs can just be handwritten in order for them to save from printing expenses. Some teachers would willingly allow handwritten outputs but some would insist in passing an encoded one.

The challenge in managing the expenses among all senior high school ABM students is inevitable. However with proper budgeting and more knowledge about their financial responsibility and status, the less they will engage in debt (Norvilitis et al, 2006). Thus, ABM students should learn how to set priorities and be strategic on where to allocate their available finances.

\section{Implication:-}

The needs and challenges revealed in this study were encapsulated in the following themes: a) 'Clamor for Work Immersion' which explains the need to expose the learners to hands on real world business activities; b) 'Demand for Learning Resources and Facilities' which entails the need for adequate print and non-print learner's material, computers, and unlimited internet access; c) 'Request for Skilled and Experienced Teachers' which relates the need to hire teachers who are business graduates or have firsthand business experience; d) 'Time runs fast' which reveals the challenge of allocating enough time in all their projects particularly those involving data gathering outside 
school; and e) 'Funds empty fast' which shows the challenge of budgeting their allowances to be sufficient for their school requirement expenses.

In light of the findings, the school administration and teachers shall then address the needs through enhancing the work immersion plan, intensifying the school improvement plan, and hiring of qualified teachers. To cope with the challenges, the students need to develop time management skills and properly set priorities on where to allocate their available finances. Since the study focuses only in one public secondary school which is its limitation, future studies may widen the coverage of its informants which may include ABM students coming from public and private schools or from urban or rural areas. Its focus may also include the needs and challenges of the entire senior high school students from various tracks and strands. The next study may cover also the lived experiences of being a senior high school student especially that the program is still in its infancy stage. Quantitative or mixed method approach may be employed in these studies.

\section{References:-}

1. Berry, P. (2013). The Impact of Globalization and Technology on Teaching Business Communication: Reframing and Enlarging World View, Methods, and Content. American Journal of Business Education, 6(1), 57-66.

2. Chia, R., \& Holt, R. (2008). The nature of knowledge in business schools. Academy of Management Learning \& Education, 7(4), 471-486.

3. Creswell, J. (2016). Research Design.: Qualitative, Quantitative, Mixed Methods Approaches.

4. Estonanto, A. J. J. (2017). Acceptability and Difficulty of the STEM Track Implementation in Senior High School. Asia Pacific Journal of Multidisciplinary Research, 5(2), 43-50.

5. Guerriero, S. (2013). Teachers' pedagogical knowledge and the teaching profession. OECD. Accessed April, 17, 2018.

6. Henard, F., \& Leprince-Ringuet, S. (2008). The path to quality teaching in higher education. Paris: OCED Publication.-2008.

7. Higgins, S., Xiao, Z., \& Katsipataki, M. (2012). The impact of digital technology on learning: A summary for the education endowment foundation. Durham, UK: Education Endowment Foundation and Durham University.

8. Island, P. E. (2008). Evaluation and Selection of Learning Resources: A Guide.

9. Jonassen, D., \& Land, S. (Eds.). (2012). Theoretical foundations of learning environments. Routledge.

10. Limon, M. R. (2016). The Effect Of The Adequacy Of School Facilities On Student Performance And Achievement In Technology And Livelihood Education. International Journal of Academic Research in Progressive Education and Development, 5(1), 45-58.

11. McHann, J. C., \& Frost, L. A. (2010). Integrating experiential learning into business courses: Using learning journals to create living case studies. American Journal of Business Education, 3(8), 1-12.

12. Merriam, S. B., \& Tisdell, E. J. (2015). Qualitative research: A guide to design and implementation. John Wiley \& Sons.

13. Misra, R., \& McKean, M. (2000). College students' academic stress and its relation to their anxiety, time management, and leisure satisfaction. American journal of Health studies, 16(1), 41.

14. Nasrullah_PhD, S., \& Khan_PhD, M. S. (2015). The impact of time management on the students' academic achievements.

15. Norvilitis, J. M., Merwin, M. M., Osberg, T. M., Roehling, P. V., Young, P., \& Kamas, M. M. (2006). Personality factors, money attitudes, financial knowledge, and credit-card debt in college students 1. Journal of applied social psychology, 36(6), 1395-1413.

16. Okabe, M. (2013). Where does Philippine education go?: the" K to 12" program and reform of Philippine basic education.

17. Park, C. (2003). Engaging students in the learning process: The learning journal. Journal of Geography in Higher Education, 27(2), 183-199.

18. Pfeffer, J., \& Sutton, R. I. (2000). The knowing-doing gap: How smart companies turn knowledge into action. Harvard business press.

19. Poser, B. (2003). Time management for students. Counselling and Development Centre, York University. Retrieved May, 1, 2017.

20. Prince Edward Island, Department of Education (2008). Evaluation and Selection of Learning Resources: A Guide. Canada: PEI, Department OF Education

21. Robbins, P. E., \& Aydede, M. E. (2009). The Cambridge handbook of situated cognition. Cambridge University Press.

22. Stollak, M., Vandenberg, A., Steiner, K., \& Richards, J. (2011). Student budgeting and spending behaviors: a comparative study. Journal of Behavioral Studies in Business, 3, 1. 